DOI: 10.46340/eppd.2020.7.6.17

\author{
Vadym Konoval, PhD in Public Administration \\ ORCID ID: https://orcid.org/0000-0003-3856-0989. \\ Directorate for National Informatization Program Development of the Ministry \\ of Digital Transformation of Ukraine
}

\title{
PHILOSOPHICAL UNDERSTANDING OF NETWORK TECHNOLOGIES: POLITICAL ASPECT
}

\author{
Вадим Коновал, к. держ. упр. \\ Директорат розвитку Національної програми інформатизації Міністерства \\ цифрової трансформації України
}

\section{ФІЛОСОФСЬКЕ РОЗУМІННЯ МЕРЕЖЕВИХ ТЕХНОЛОГІЙ: ПОЛІТИЧНИЙ АСПЕКТ}

The article solves an urgent scientific problem, which consists in the study of philosophical concepts of network technology development through the prism of social reality in the conditions of digital transformations in Ukraine. The rapid development of the digital age requires an indepth study of the formation of a new type of society - digital one, which is considered from the standpoint of social phenomena and processes.

The modern world is built as a global network, and thus it is radically different from the industrial age, which is based on the principle of a hierarchical pyramid. It is established that network analysis allows to study the political process in a fundamentally new context, explaining how interest groups, political parties, bureaucracy, political leaders influence the process of designing public policy by forming different types of network structures. The theory of network technologies and social object is studied together with the study of its network effect. It is proved that modern philosophy is actively exploring the global dimension of networks as a technology, and a new view of social reality. Theoretical developments (those that explain the reasons for the emergence and widespread use of network alliances in the field of public policy and public administration practice) have developed in several directions. Western scholars believe that political networks are the answer to the need for horizontal coordination of efforts to solve problems in complex and more differentiated and dynamic society.

Theoretical approaches are described, which consist in considering political networks as a strategic reaction of political actors to the need to exchange tangible and intangible resources within the public sector fragmented by administrative reforms. Based on this, on the background of a wide range of theories, that in their own way explaine the reasons for the spread and popularity of networks in the socio-political environment, we can not ignore the political conditionality of this phenomenon: the crisis of the welfare state and neoliberal model. The author of the study proves that political networks provide an opportunity to mobilize knowledge, resources and efforts of free and responsible citizens, civil society, local government, private companies, creating a basis for "co-management" of the state, establishing the essence of relations between state and nonstate institutions, those ones that comply with the modern socio-economic requirements. The features of the modern management model of the "network" are singled out.

Keywords: information, information society, network, networking technologies, social network.

Постановка проблеми. Незважаючи на економічні, політичні та безпекові складнощі, Україна активно інтегрується в світовий глобальний цифровий простір, розвиваючи й освоюючи новітні інформаційно-комунікаційні технології, вирішуючи проблеми свободи та цифрові права 
у сфері інформації, формуючи законодавчу базу, що регулює інформаційну цифрову діяльність тощо. Цей процес не може не супроводжуватися, а іноді i випереджатися, утвердженням філософського світогляду, у зв'язку з чим доцільно виробити чітке уявлення про характер взаємозалежності технологічних і світоглядних складових реальності цифрового суспільства, яке формує "мережева технологія".

Актуальність дослідження обумовлена тим, що існує потреба глибокого дослідження становлення нового типу суспільства - цифрового, яке розглядається з позиції соціального явища і процесу. На нашу думку, варто здійснити теоретико-філософський аналіз мережевих технологій у сучасних умовах цифрового розвитку, проаналізувати філософське осмислення поняття "мережеве суспільство", його особливостей, причин та умов розповсюдження в світі, зокрема в сфері цифрової трансформації. Якісно побудована мережа електронного урядування позитивно впливає на ефективність та результативність загального ходу змін та трансформаційні перетворення в українському суспільстві. У праці автором використані філософські та загальнонаукові методи дослідження.

Аналіз останніх досліджень і публікацій. Дослідженню проблемних питань виникнення та розвитку "мережевої технології" присвячені праці зарубіжних науковців, зокрема: В. Аршинов ${ }^{1}$, Ю. Данилов ${ }^{2}$, В. Тарасенко ${ }^{3}$, В. Бугорський ${ }^{4}, \quad$ П. Бурдьє ${ }^{5}$, Е. Гідденс ${ }^{6}, \quad$ В. Декомб ${ }^{7}$, Ж. Делез ${ }^{8}$, М. Ельчанинов ${ }^{9}$, В. Емелин ${ }^{10}$, М. Кастельс ${ }^{11}$, Д. Норт ${ }^{12}$, Ф. Уебстер ${ }^{13}$ та інші.

Варто зазначити, що сфера емпіричних досліджень мережевої технології, у тому числі і "мережевого суспільства", значно переважає над теоретичними дослідженнями, а часом і зовсім не підкріплена теорією та обгрунтуванням практично досліджуваних питань. Зарубіжні науковці досліджують "мережеве суспільство" не одне десятиліття, а українські - порівняно нещодавно.

Зважаючи на цю проблематику, питання теоретико-філософський аналізу мережевих технологій у сучасних умовах суспільного розвитку держави залишаються недостатньо розробленими та висвітленими.

Метою статті $є$ здійснити теоретико-філософський аналіз мережевих технологій у сучасних умовах суспільного розвитку, продемонструвати філософське осмислення поняття "мережеве суспільство", його особливостей, причин та умов розповсюдження в світі, зокрема в сфері електронного урядування, розкрити зміст філософських концепцій мережевих технологій, цифровізації та цифрової трансформації тощо.

Основні результати дослідження. Проблема мережевих технологій та мережевого суспільства застала соціальну науку зненацька, незважаючи на те, що соціальні мережі існували завжди. Найбільш досліджувані роботи з даної тематики належать науковцю М. Кастельсу ${ }^{14}$. Науковець вперше розробив теоретичні узагальнення щодо природу мережевих технологій та суспільства і ввів наступні фундаментальні поняття: "потоків", "інформаційного суспільства" і т. д. М. Кастельс у своїх дослідженнях відштовхується від реєстрації змін, що відбуваються, та описує їх кількісні характеристики.

Роздуми про мережеве суспільство вчений вбудовує в більш широкий контекст технологічної революції та теорії інформаційного суспільства. М. Кастельс констатує факт трансформації

\footnotetext{
${ }^{1}$ Аршинов, В. И., Данилов, Ю. А., Тарасенко, В. В. (1997). Методология сетевого мышления. Феномен сетевой самоорганизации. Онтология и эпистемология синергетики. Москва: ИФ РАН, 18.

2 Там само.

3 Там само.

${ }^{4}$ Бугорский, В. Н. (2007). Сетевая экономика. Москва: Финансы и статистика, 156.

5 Бурдье, П. (2005). Поле литературы. В: Социальное пространство: поля и практики. Сборник статей. СПб: Алетейя, 365-472.

${ }^{6}$ Гидденс, Э. (2005). Устроение общества: Очерк теории структураџии. Москва: Академический проект, 58.

7 Декомб, В. (2000). Современная франиузская философия. СПб: Весь Мир, 131.

8 Делез, Ж., Гваттари, Ф. (1996). Философия эпохи постмодерна. Минск, 6-31.

${ }^{9}$ Ельчанинов, М. С. (2005). Социальная синергетика и катастрофы России в эпоху модерна. Москва: КомКнига.

${ }^{10}$ Емелин, В. (2020). Ризома и Интернет. Емелин Вадим <http://emeline.narod.ru/rhizome.htm>. (2020, листопад, 15).

${ }^{11}$ Кастельс, М. (2004). Галактика Интернет: Размылления об Интернете, бизнесе и обществе.

Екатеринбург: У-Фактория, 155.

12 Норт, Д. (1997). Институты, институцииональные изменения и функционирование экономики. Москва: Начала.

13 Уэбстер, Ф. (1999). Теории информационного общества. Москва; Уэбстер, Ф. (2004). Теории информационного общества. Москва, 306.

${ }^{14}$ Кастельс, М. (2000). Информаџионная эпоха: экономика, общество и культура. Москва: ГУ ВШЭ.
} 
соціальності в сучасному суспільстві. Соціолог погоджується з визначенням Б. Велмана щодо включає поняття мережі: "Спільноти - це мережі міжособистісних зв'язків, що забезпечують соціальну взаємодію, підтримку, інформацію, почуття приналежності до групи та соціальну ідентичність" ${ }^{1}$. Якщо раніше основу всякого людського співтовариства становила прив'язаність людини до місця проживання та роботи, то на даний час актуальним є ослаблення цієї прихильності і перехід до більш слабким екстериторіальним соціальних зв'язків. Люди втрачають зв'язок з локальними спільнотами не тільки в силу нових комунікаційних можливостей, але і в силу того, що вони реалізують особисті потреби, спираючись на ці нові можливості. Цей принцип побудови спільнот М. Кастельс називає мережевим індивідуалізмом, персоналізованим співтовариством. На думку науковця, формується нове середовище життєтворчості, в якій змінюється зміст простору та часу.

Поняття «мережа» широко застосовується в природничих і точних науках. В останнє десятиліття воно стало відображенням нової парадигми в політичній науці, що покликана відобразити складну структуру політичних відносин. На сучасному етапі ця проблематика $\epsilon$ одним із магістральних дослідних напрямів, оскільки пропонує як нові способи дослідження політичного простору, так і нові, більш ефективні технології розроблення та реалізації державної політики в умовах зміни ролі держави, ускладнення та ресурсного посилення позицій державних діячів.

У літературі сформувалося в цілому позитивне ставлення до мережевої концепції. Представники різних шкіл мережевого аналізу, виходячи із специфіки досліджень, що проводяться, звертають увагу на низку його суттєвих переваг. Наприклад, для американських дослідників важливо, що мережевий аналіз дозволяє досліджувати політичний процес у принципово новому контексті, пояснюючи, яким чином групи інтересів, політичні партії, бюрократія, політичні лідери впливають на процес проектування державної політики шляхом формування різних видів мережевих структур ${ }^{2}$.

Німецькі дослідники переконані, що мережева теорія справить суттєвий вплив на розвиток соціальної теорії, оскільки вона пояснює не лише інституціональну організацію політики, а й складні неформальні відносини між учасниками політичного процесу ${ }^{3}$.

Представники британської школи, через десять років після написання першої роботи, що стала класичною, присвяченою політичним мережам, дійшли висновку, що ця теорія має колосальний пізнавальний потенціал, відображаючи всю складність політико-адміністративного процесу в постіндустріальних країнах 4 .

Теоретичні розробки, що пояснюють причини виникнення та широкого поширення мережевих альянсів у сфері публічної політики та практиці державного управління, розвивалися в декількох напрямах. Західні вчені Я. Куіман та Р. Майнц вважають, що політичні мережі є відповіддю на потребу в горизонтальній координації зусиль з вирішення проблем в ускладненому та більш диференційованому й динамічному суспільстві ${ }^{5}$.

Представники теорій взаємозалежності Р. Родес і В. Кікерт, а також Е. Клейн та Д. Коппеньян розглядають політичні мережі як стратегічну реакцію політичних акторів на необхідність обміну матеріальними й нематеріальними ресурсами всередині фрагментованого адміністративними реформами державного сектора ${ }^{6}$.

Дослідники, які досліджують соціологію організації, Д. Марш і Р. Олсен розуміють політичні мережі як нормативну реакцію на надлишок суспільного та державного в житті індивіда та нестачу ринкових взаємодій ${ }^{7}$.

Структуралісти М. Фуко та Н. Роуз трактують політичні мережі як частину прогресивної моделі ліберального державного управління, що стимулює здійснення «правління на відстані» шляхом

\footnotetext{
${ }^{1}$ Wellman, C. (2000). Physical place and cyberplace: the rise of networked individualism. International Journal of Urban and Regional Research, 2000/1.

${ }^{2}$ Campbell, J. (1989). Afterword on Policy Communities: A Framework for Comporative Research. Governance, 87.

${ }^{3}$ Kenis, P. (1991). Policy Networks and Policy Analysis: Scrutinizing a New Analytical Toolbox. In: Martin, B.,

Mayntz, R. (eds.) (1991). Policy Networks. Empirical Evidense and Theoretical Considerations. - Frankfurt-um-Main: Westview Press, 67.

${ }^{4}$ Rhodes, R.A.W. (1997). Understanding Governance: Policy Networks, Governance, Reflexivity and Accountability. Buckingham: Open University Press, 35.

${ }^{5}$ Kooiman, J. (1993). Modern Governance. New Government - Society Interaktions. London: SAGE Publications Ltd, 26.

${ }^{6}$ Rhodes, R.A.W. (1997). Understanding Governance: Policy Networks, Governance, Reflexivity and Accountability.

Buckingham: Open University Press, 22.

${ }^{7}$ Marsh, J. G., Olsen, J.P. (1995). Democratic Governance. New York: The Free Press.
} 
мобілізації плюральності акторів, які здатні до саморегулювання, а також мереж в заданих інституціональних межах, що забезпечують необхідний рівень лояльності ${ }^{1}$.

Виходячи з цього, на тлі широкого спектру теорій, по-своєму пояснюючих причини поширення та популярності мереж в соціально-політичному середовищі, не можна знехтувати політичну обумовленість цього явища: криза моделі держави всезагального добробуту, а також неоліберальної моделі.

Якщо державу всезагального добробуту звинувачують в необгрунтовано високих витратах, то неоліберальні уряди поклали надмірні сподівання на квазіринкові структури в державному секторі. Політичні мережі дають можливість мобілізувати знання, ресурси та зусилля вільних і відповідальних громадян, структур громадянського суспільства, місцевої влади, приватних компаній, створюючи основу для «співуправління» державою, встановлення сутності взаємовідносин між державними та недержавними інститутами, що відповідають сучасним соціально-економічним вимогам.

Таким чином, мережеве управління становить реалізацію тенденції переходу від ієрархічного управління до управління шляхом ведення переговорів, узгодження інтересів, формування низки децентралізованих добровільних об'єднань, поєднуючи (концентруючи) в собі наступні ознаки:

існування декількох центрів прийняття рішень; відсутність чіткої ієрархії між зазначеними центрами; мережева форма організації взаємодії між суб'єктами залучення до процесу прийняття рішень; динамізм і нечіткість рамок мереж; учасниками взаємодії є представники експертної спільноти, організації приватного сектору, некомерційні структури; управлінський процес грунтується на переговорних процедурах, пошуку консенсусу, укладенні угод, співробітництві; превалювання горизонтальних відносин між суб'єктами неформальних моделей прийняття рішень; державні інститути не відіграють домінуючої ролі у взаємодії.

Водночас, держава може вирішувати багато проблем, забезпечувати надання широкого кола послуг за допомогою мереж. Проте з цією діяльністю пов'язані також суттєві виклики реалізації ідей цієї управлінської парадигми, що вимагає від політиків і державних менеджерів принципово нових знань, умінь і навичок.

По-перше, формуючи мережі, вони мають бути впевнені в тому, що інтереси суспільства належно захищені від підміни вузькоклановими інтересами.

По-друге, вони мають розуміти, що управління за допомогою мереж $\epsilon$ достатньо складним процесом, оскільки існує нескінченна кількість ситуацій, в яких щось може піти не так, як було заплановано ${ }^{2}$.

Основна перешкода пов'язана 3 тим, що державні організації, від яких вимагається бути не лише успішними учасниками мереж, а й нерідко координуючими та керуючими структурами, створювалися для функціонування в умовах бюрократичної моделі управління, а не мережевої.

Управління мережею, або декількома мережами не є ідентичним управлінню штатними співробітниками відомства та владному розподілу обов'язків. Виходячи 3 цього, якість мережевого управління та можливість реалізації цієї парадигми в практиці державного управління відповідних країн буде залежати не в останню чергу від системи підготовки державних службовців, готових не лише підпорядковуватися, а й ініціювати нові взаємодії за межами ієрархії․

Еволюція моделей державного управління була викликана необхідністю забезпечити високий рівень адаптивної ефективності складно організованим політичним системам, що перебувають під тиском комплексу внутрішніх і зовнішніх факторів, неприйняття яких до уваги поставило б під загрозу збереження владних позицій діючою політичною елітою. Гостра політична конкуренція в демократичних країнах стала стимулом для пошуку нових методів, технологій та інструментів державного управління в кризових соціально-політичних і економічних умовах, забезпечивши в результаті високий рівень відкритості та гнучкості політико-адміністративної діяльності за одночасного збереження інституціональної стабільності.

Дослідження еволюції моделей державного управління дало можливість зробити висновок про те, що управлінські можливості держави та ефективність розроблення й реалізації державної політики в різних галузях підвищується не стільки за рахунок упровадження в практику його діяльності ринкових механізмів, скільки за рахунок розширення горизонтальних, невладних контактів із недержавними акторами на основі ресурсних взаємозалежностей, що створюють новий,

\footnotetext{
${ }^{1}$ Foucault, M. (1991). Hemel Hempstead: Harvester Wheatsheaf. Government, 29.

${ }^{2}$ Donahue, J. (1989). The Privatization Decision: Public Ends, Private Means. N.Y.: Basic Books.

${ }^{3}$ Stark, D. (2009). The Sense of Dissonance: Accounts of Worth in Economic Life. NJ: Princeton University Press.
} 
партнерський формат відносин держави з їі контрагентами. Водночас, практика реформ продемонструвала недосконалість ідеї цілковитої відмови від ієрархічної координації та традиційної моделі державного управління, оскільки саме бюрократія в певному сенсі є гарантом дотримання суспільного інтересу та обмежує домінування вузькогрупових інтересів бізнесу, що вступає в партнерські відносини з державою ${ }^{1}$.

У сучасних умовах спонтанно та цілеспрямовано мережеві альянси, що формуються, вбудовуються в традиційну практику державного управління, не відкидаючи ієрархії, вносячи при цьому необхідну гнучкість, креативність, мобільність у діяльність державних службовців, а також відкриваючи для них нові перспективи професійного зростання. Сучасне управління державою - це управління в формі «governance», що розуміють як підтримання координації та узгодженості в діях різноманітних індивідуальних акторів, державних інститутів, груп інтересів, добровольчих організацій і наднаціональних структур в умовах постійного ускладнення соціально-політичної ситуації, що грунтується на партнерській моделі прийняття рішень ${ }^{2}$. На всіх управлінських рівнях держава змушена ініціювати створення комунікативних майданчиків з метою зближення або подолання вузькогрупового бачення проблем ключовими акторами різних політичних доменів. Таким чином, сучасна управлінська модель передбачає:

- подолання доцентрових сил у досить фрагментованому суспільстві, в якому його групи перебувають у відносинах взаємозалежності;

- відновлення ресурсного дефіциту, що має держава, в процесі розроблення та реалізації рішень;

- опору на мережеві альянси, що забезпечують представлення та узгодження різних інтересів у сфері публічної політики;

- створення середовища та умов для взаємодії, що стимулюють учасників мережевих альянсів демонструвати свою готовність вступати в переговорний процес і спільно віднаходити компромісні варіанти рішень, а також готовність і відкритість до навчання, сприйняття нового досвіду;

- використання слабкоформалізованих моделей та процедур прийняття рішень.

Парадоксально, але беручи на озброєння принципи й технології мережевого управління, держава не стільки долає невизначеність, скільки провокує іiі, адаптуючись таким чином не до конкретних викликів із ззовні чи із середини, а до ситуації невизначеності в цілому, віднаходячи в ній нові можливості для розвитку та здійснення інновацій й пошуку проблем.

Висновки та перспективи подальших досліджень. Сучасний світ побудований як цифрова мережа. Цим він докорінно відрізняється від індустріальної епохи, в якій царював принцип ієрархічної піраміди, але тепер вона не актуальна. Мережева організація становиться правлячою в житті людства і продовжує займати домінуюче становище в світі, адже мережа охопила найголовніші сфери суспільства: економіку, політику, безпеку, культуру тощо. Люди самі намагаються об’єднатися в мережі і тим самим полегшити собі оn-line життя через Інтернет речі.

Глобалізація пов'язала воєдино всі центри економічної активності у всіх країнах, навіть якщо більшість видів діяльності, робочих місць і людей все ще залишаються національними і локальними.

Мережеві технології дозволяють по-новому подивитися на суспільство, більш того, можна стверджувати, що вони призводить до зміни кута зору в суспільстві. Описані теоретичні підходи полягають у постановці в центр уваги соціальної комунікації та соціальних контактів. Соціальний контакт, утворює зміст поняття соціальності, в різних наукових традиціях розуміється по-своєму: як дія, як матеріальний обмін, як мовне спілкування, як нормативний або інституціональний зв'язок, інтеракція.

Можна визначити наступні основні особливості мережевих технологій у суспільства:

- мережі $є$ найбільш успішними та конкурентоспроможними проектами в економіці, фінансах, культурі (вони все частіше заявляють по себе в політиці, витісняючи вимираючі ієрархічні структури - партіі);

- знання та інформація є головними джерелами конкурентоспроможності;

- в мережі головною діючою особою $є$ активна особистість, довкола якої формуються взаємовідносини;

\footnotetext{
${ }^{1}$ Норт, Д. (1997). Институты, институцииональные изменения и функционирование экономики. Москва: Начала.

2 Puerre, J. (2005). Debating Governance. Oxford: Oxford University Press, 8.
} 
- не лише мережі об’єднують соціальних суб'єктів, але і ці суб'єкти, включаючись в різні мережі, здатні сполучати їх;

- ієрархія в мережі децентралізована, де існують декілька лідерів;

- набувають розвитку неформальні відносини, які іноді важливіші за формальні;

- мережеві технології створюють зв'язки, які породжують нелінійності та є мінливими, існують недовго, тобто, якщо змінюються завдання, то руйнуються вчорашні союзи та виникають нові.

Мережеві технології дозволяють моментально і майже без зайвих витрат часу, сил та енергії встановити велику кількість прямих контактів і цим полегшує виявлення партнерів, тому знайти людей з необхідними якостями в умовах Мережі набагато простіше, ніж при використанні будь-якої іншої форми взаємодії.

Сучасна філософія активно досліджує мережу та історію становлення мережевий технологій. Ця проблематика $є$ одним із перспективних дослідницьких напрямів, оскільки пропонує як нові способи дослідження суспільного простору, так і нові, більш ефективні технології розроблення та реалізації державної політики в умовах зміни ролі держави, ускладнення та ресурсного посилення позицій суспільних гравців.

\section{References:}

1. Arshinov, V. I., Danilov, Yu. A., Tarasenko, V. V. (1997). Metodologiya setevogo myshleniya. Fenomen setevoy samoorganizatsii. Ontologiya i epistemologiya sinergetiki [Methodology of network thinking. The phenomenon of network self-organization. Ontology and epistemology of synergetics]. Moscow: IF RAN. [in Russian].

2. Bugorsky, V. N. (2007). Setevaya ekonomika [Network economy]. Moscow: Finance and Statistics. [in Russian].

3. Bourdieu, P. (2005). Pole literatury [Literature field]. V: Sotsialnoye prostranstvo: polya i praktiki. Sbornik statey [In: Social space: fields and practices. Digest of articles]. SPb: Aleteya, 365-472. [in Russian].

4. Giddens, E. (2005). Ustroyeniye obshchestva: Ocherk teorii strukturatsii [Organization of society: An outline of the theory of structuration]. Moscow: Academic project. [in Russian].

5. Decombe, W. (2000). Sovremennaya frantsuzskaya filosofiya [Contemporary French philosophy]. St. Petersburg: All the World. [in Russian].

6. Deleuze, J., Guattari, F. (1996). Filosofiya epokhi postmoderna [Philosophy of the postmodern era]. Minsk. [in Russian].

7. Elchaninov, M.S. (2005). Sotsialnaya sinergetika i katastrofy Rossii v epokhu moderna [Social synergetics and catastrophes of Russia in the era of modernity]. Moscow: KomBook. [in Russian].

8. Yemelin, V. (2020). Rizoma i Internet [Rhizome and the Internet]. Yemelin Vadim <http://emeline.narod.ru/rhizome.htm>. (2020, November, 15). [in Russian].

9. Castells, M. (2004). Galaktika Internet: Razmyshleniya ob Internete, biznese i obshchestve [The Internet Galaxy: Reflections on the Internet, Business and Society]. Yekaterinburg: U-Factoria. [in Russian].

10. Castells, M. (2000). Informatsionnaya epokha: ekonomika, obshchestvo i kultura [Information Age: Economy, Society and Culture]. Moscow: SU HSE. [in Russian].

11. Koshelkin, A. V., Musin, M. M. (2003). Matritsy vliyaniya. Teoriya i praktika ekonomicheskogo upravleniya [Influence matrices. Theory and practice of economic management]. Moscow. [in Russian].

12. Nort, D. (1997). Instituty, institutsionalnyye izmeneniya i funktsionirovaniye ekonomiki [Institutions, institutional change and economic performance]. Moscow: Beginnings [in Russian].

13. Taratuta, E.E. (2007). Filosofiya virtualnoy realnosti [Philosophy of virtual reality]. St. Petersburg. [in Russian].

14. Webster, F. (1999). Teorii informatsionnogo obshchestva [Information Society Theories]. Moscow. [in Russian].

15. Webster, F. (2004). Teorii informatsionnogo obshchestva [Information Society Theories]. Moscow. [in Russian].

16. Burt, R. (2001). The Social Capital of Social Holes. In: Guillen M., Collins R., England P. (2001). New Directions in economic Sociology. N.Y., 201-246. [in English].

17. Campbell, J. (1989). Afterword on Policy Communities: A Framework for Comporative Research. Governance, 87. [in English].

18. Donahue, J. (1989). The Privatization Decision: Public Ends, Private Means. N.Y.: Basic Books. [in English].

19. Foucault, M. (1991). Hemel Hempstead: Harvester Wheatsheaf. Government. [in English]

20. Habermas, J. (1998). Faktizitat und Geltung [Factuality and effectiveness]. Frankfurt-um-Main. [in Deutch].

21. Kenis, P. (1991). Policy Networks and Policy Analysis: Scrutinizing a New Analytical Toolbox. In: Martin, B., Mayntz, R. (eds.) (1991). Policy Networks. Empirical Evidense and Theoretical Considerations. Frankfurt-um-Main: Westview Press. [in English].

22. Kickert, W.J.M., Klijn, E.-H., Koppenjan, J.F.M. (1997). Managing Complex Networks: Strategies for the Public Sektor. London: Sage. [in English].

23. Kooiman, J. (1993). Modern Governance. New Government - Society Interaktions. London: SAGE Publications Ltd. [in English]. 
24. Luhmann, N. (1992). Kontingenz als Eigenwert der modernen Gesellschaft [Contingency as an intrinsic value of modern society]. Opladen. [in Deutch].

25. Marsh, J. G., Olsen, J.P. (1995). Democratic Governance. New York: The Free Press. [in English].

26. Mayntz, R. (1993). Modernization and the Logic of Interorganizational Networks. Aldershot: Amesbury. [in English].

27. Puerre, J. (2005). Debating Governance. Oxford: Oxford University Press. [in English].

28. Rhodes, R.A.W. (1997). Understanding Governance: Policy Networks, Governance, Reflexivity and Accountability. Buckingham: Open University Press. [in English].

29. Rose, N. (1999). Powers of Freedom: Reframing Political Thought. Cambridge: Cambridge University Press. [in English].

30.Stark, D. (2009). The Sense of Dissonance: Accounts of Worth in Economic Life. NJ: Princeton University Press. [in English].

31. Wellman, C. (2000). Physical place and cyberplace: the rise of networked individualism. International Journal of Urban and Regional Research, 2000/1. [in English]. 